\title{
Singular individuals, conflicting authorities: Annie Besant and Mohandas Gandhi
}

The pluralisation of authority in late 19th /early 20th century colonial India as it was asserted, appropriated, redistributed, reformulated or challenged from below generated conflicting sources of validation - divine, sovereign, patriarchal, knowledge-based. The complexity of this background complicates understandings of the national provenance of religions, as well as of the social, political and ideological semiotics that surround the inclination to faith and position it within comparative frameworks. As I have said elsewhere, 'What came to be described as legitimated European knowledges were hybrid formations that enfolded and systematised "other" knowledges, other hierarchies. [Indian] "local” knowledge transformed into European knowledge often travelled back into indigenist claims, and performed different functions in European and Indian locales' (Sangari 1999, xxxiv). The internationalisation of anti-imperialist and anticolonial sentiments not only mediated indigenist claims but created new non-national circuits of solidarity and identity that could amplify the boundaries of a self. A tension between received, recrafted and experiential knowledge, between freely chosen affiliations and determining structures, between authorities and individualisation inhered in colonial and metropolitan circulations and interactions.

At this historical conjuncture, the discursive imbrication of divine, sovereign, and patriarchal power, the intertwined conceptions of the religious, political, social, biological, and domestic in Britain and India make isolating religious individualisation problematic. As is now evident, what were named the national culture of England and civilizational heritage of India were jointly shaped through the institutional apparatus of colonialism and the circulation of colonial and metropolitan actors and/or ideas in ways that cannot be captured in insular vocabularies of autochthonous religions, unified regions or homogenous nations. Annie Besant's discovery of an ancient 'Hinduism' and Mohandas Gandhi's initial reformulation of 'his' Hinduism and Indianness in Britain are in fact signs of a Britain transformed and permeated by empire. What is more, Hinduism, newly defined as a single religion, and Theosophy, a new religion that drew on Buddhism and Hinduism, were in the making across national boundaries.

Hinduism was a construction zone through the 19th century with several competing builders - missionary, colonial, orientalist, Indian reformist and antireformist individuals and organisations - none of these had a monopoly yet many recycled the same prefabricated bricks in pursuit of their goals. Theosophy 
too devised a pedagogic and occult version of Hinduism. In these religions in the making, individualisation could take place through and against an array of authorities - affirming some and critiquing others, and thus simultaneously signifying voices that were normative and resistant, conservative and dissenting, unoriginal and innovative. Individualisation appears to be constellative, conjunctural, and a shifting process (see Fuchs 2015, 15).

Annie Besant could be characterised as a transnational actor who made India her base, adopted Theosophy and Hinduism, deviated from social and familial norms before and after her conversion as well as embraced the 'other' via an aggrandised ancient Hinduism. Mohandas Gandhi was a transnational actor whose early conception of Hinduism crystallised in his student years in London and expatriate decades in South Africa. Gandhi evolved into a nationalist and world-historical figure, and through his innovative practices later rejected Hinduism as a boundary-marker. Both crossed cultural boundaries experientially and displayed a remarkable personal openness to syncretic spirituality that did not synchronise with their gendered religio-civilisational imaginaries of ancient India.

This essay does not systematically address their prolific writing, multiple public personae and changing political positions and nor does it map personal interactions and differences - only some aspects are pertinent here. Both spent formative years in London - a metropolitan zone of accumulation, display, dissemination and translation of 'knowledge' as well as a milieu that often threw up vexed combinations of imperialist hierarchies, heterodox dissent and anticolonial or anti-imperialist sentiments. India inhabited the Anglo-European archive and the public sphere. Britain brimmed with imperial propaganda, discussion, and representation of colonial rule in political and parliamentary debates while reformist debates on child marriage and the age of consent took place simultaneously in India and Britain. At the same time, a largely middle-class non-conforming fringe was engaged in comparative and critical evaluations of religions including Christianity as well as critiques of British colonisation and patriarchal marriage practices. Within this, there were several overlaps, affinities or intersections between late Victorian heterodoxy and radicalism, often utopian and anticolonial, as well as 'easily transferable sympathies' between some Utopian Socialists, Fabians, Secularists, Theosophists and other occultists, Vegetarians, Humanitarians, Irish nationalists, feminists, suffragettes and spiritualists (Anderson 1994, 566; Jayawardena 1995, 107-10, 113-4; Veer 2001, 59-65; L. Gandhi 2006, 77-80, 121-25, 177; Miller 2009, 244, 249; Beaumont 2010, 223-25; Miller 2013, 255-56; Malinar 2018). The Victorian entanglement of the social and spiritual, often infused with Orientalism and 'eastern' religions, could bifurcate into progressive and traditional positions on the 'woman question' or combine them in a 'spiritualized feminism' (Owen 2004, 26-27, 87-88). What is 
more, liberal dissent at home by the British did not always preclude support of British imperialism (Viswanathan 1998, 185-87; L. Gandhi 2014, 7-9). With some exceptions, London's liberal, socialist, Fabian and radical anticapitalist dissidents mostly subscribed to racial hierarchy filtered through evolutionary theory (see Viswanathan 1998, 196; Schneer 2001, 164-71). Indeed, a racialised concept of cultural exceptionalism, which matched the racialisation it sought to resist, entered some Indian political demands for self-government.

Besant outgrew Anglican Christianity, traversed a critical constellation of atheism, an individualist Secularism that rejected Christian doctrine, Socialist activism, feminist struggles for women's individual rights to birth control, property and suffrage, demands for trade union protection as well as Home Rule for the Irish. Most of her former political ties and several friendships dissolved after adopting Theosophy. Gandhi interacted with a similar radical fringe in London Socialists, esoteric Christians, Theosophists, Vegetarians, Union of Ethical Societies, liberals, suffragettes, anti-imperialists, and had feminist, socialist, pacifist and Theosophist interlocutors in South Africa. He moved from an admiring to an uneasy then critical relation to Theosophists and their occult predilections as well as Besant who he first met in London just after her conversion. Besant disengaged from her earlier activism and re-entered serious political activity two decades after she came to India in 1893. Gandhi's stake was already high when he wrote Hind Swaraj on a return voyage from Britain to South Africa. Although Gandhi was still a loyalist and Home Rule was the political horizon for him, Besant and other nationalists, he was developing a scalar and synchronic view of the intersecting materiality and contradictions of labour and capitalism in three countries, each in the grip of dislocating transitions and labour struggles. Through the experience of official discrimination, imprisonment, racist physical violence and proto-apartheid, and as witness to the brutal formation of a united white ruling class and a unified nation in South Africa after the Anglo-Boer war, his views on race had become self-contradictory, yet his campaigns maintained a studied distance from native Africans (Hunt 1993, 52; Habib 2011, 3-6; Lelyveld 2012, 59-60; Desai and Vahed 2016, 42-44, 122-23). ${ }^{1}$ Initially, South Africa was a site of Indian cultural self-differentiation.

This essay sketches an ensemble of colonial reformism, indigenism, civilisational moralism, rights claims as well as antimodern disclaimers filtered through anticolonial and nationalist projects that pushes against the individualisation

1 Gandhi campaigned for licenses, rights to mobility and property for migrant Indian traders, and later against taxes on indentured workers; his prejudices too began to change. See Habib 2011, 3-4; Natarajan 2013, 73-78, 83, 91, 102; Skaria 2016, 40-41, 49-51. 
of women in Besant's Hindu Ideals (1904) and Gandhi's Hind Swaraj (1909) as well as in some early speeches and writing from the 1910s and 1920s. These texts display startling connections and converging currents as they respond comparatively to colonial England and India. Besant contrasts a materialist, contractual, individualist 'west' with a unified Hinduism committed to a non-contractual regime, sees varna (the fourfold caste order) as stabilising social functions and Hindu women as repositories of dharma/duty and tradition. Gandhi seems to make a starker civilisational opposition between east and west. Yet, both seek to align notions of a premodern and an antimodern in their definition of rights and duties; both bundle prescriptive, religious and civilisational imaginaries into the concept of marriage; and both elaborate altruism as an agential model which spans the religious, social and political. Gandhi's notable differences from Besant in these years are in the multiple inflections of dharma, rights and duty, an ascetic model of womanhood and marriage embedded in a nationalist project, and a multi-religious concept of the nation which inaugurates his later commitment to a supradenominational religious axis.

Despite the selective diversity of Besant's and Gandhi's historical repertoires and intense personalisation of their religious choices, self-making practices, and transnational combinatoires in earlier and later decades, these texts and imaginaries are implicated in the same Indian reformist and transnational Orientalist and Indological circuits that relied on textually predetermined and formulaic knowledge. Hindu or Indian women, a typified collective, are positioned in a prescriptive and repressive enclosure in which normative marriage becomes the site of deindividualisation. For Besant and Gandhi, marriage as a regulatory institution, and the women within it are seen as indispensable for the very survival of religion. In this curious inversion, that rebounds on the social and religious individualisation of women, it is not religion that protects marriage but women who protect religion.

The gaps between Besant and Gandhi's practice and prescription (to which I will return in conclusion) are significant. Even as both Britain and India are becoming 'modern', caste, rebirth, duty, dharma and Indian/Hindu womanhood are posited as antidotes to 'western' individualism. Paradoxically, Besant's and Gandhi's own individualisation as social and political actors seems to rest on its historical antagonist: a caste-based patriarchal order. The elevation of womanhood and the attraction for upper-caste regulatory marriage override the tenor of their personal disaffections. Besant separated from an oppressive husband who believed in 'a husband's authority and a wife's submission' $(1908,81)$, and though she did not reject the institution, she had demanded reform of marriage laws and protested the absence of financial, legal and social rights for married women (Owen 2004, 95; Blyth 2009, 122-23, 129). Gandhi carried the resentment 
and guilt of a teenage marriage, had spent very few years in the same household as his wife, and, between 1906 and 1909, took a vow of celibacy, turning towards anticapitalism, civil disobedience, and inner spiritual self-reform (satyagraha).

\section{Framing the antimodern}

European Enlightenment can be read as an abstract set of egalitarian values with emancipatory potentials that questioned old hierarchies and were appropriated and radicalised outside Europe as much as inside it to mobilise universal rights in colonial conditions. Alternately, it can be read as a comparative and contrastive project of European self-differentiation that incorporated the 'discovered' and conquered world into European knowledge systems, a project that was textual from its inception, drew on travelogues, novels and missionary accounts, and continued to play a shaping role in the late 19th and early 20th century (Conrad 2012, 1009-15; Hulme and Jordanova 1990, 7-8, 12). The contrastive aspect was selectively incorporated as an ideology of capitalism, which was threatened by the political concretisation of egalitarian potentials, and normative hierarchies were devised to justify class, racial and colonial domination (Sangari 1999, xxxv). Whether the counterpoints to forms of Enlightenment universalism are attributed to the ascent of notions of racial/civilisational superiority and evolutionary theory (Veer 2001, 40; Conrad 2012, 1019-20), or seen as a global partitioning of its radical strands (Stoler 2016, 234-35), or understood as a part of its open 'dialectical history of proliferation and blockage', Enlightenment ideals were not universalised in Europe and even less so in the colonies (Sangari 1999, xxxv).

In 19th century Europe, romantic organicism and evolutionary theory were the currencies of denial. In the former, 'the figure of woman serve[d] as a recurring cipher of the premodern within modernity itself', while models of evolution usually relegated women and people of colour to an archaic or atemporal zone outside the path of historical development and placed them lower on the evolutionary chain (Felski 1995, 40, 55-56, 148). In significant social domains colonial rule took place, ideologically and strategically, under the insignia of anti-Enlightenment tendencies, and was accompanied by assumptions that most Enlightenment ideals could not or must not be imitated, applied, or implemented in India. ${ }^{2}$ Further, colonisation shaped a reformist syntax in which forms of liberal universalism were uneasily

2 John Stuart Mill enunciated the 'principles of exclusion' from liberty for 'backward states of society', and saw 'despotism [as] a legitimate mode of government in dealing with barbarians' until their 'improvement' was achieved (On Liberty 1859, in Veer 2001, 17). 
entangled with indigenist invocations of patriarchal practices and Hindu women as governed by religious belief; this became part of a compliant, shared, yet reactive antimodern vocabulary by the end of the 19th century.

The common emphasis on Besant's vaunted cross-cultural hybridity and Gandhi's so-called invocation of premodern solidarities or loyalties for nationalist mobilisation thus may obscure a wider problematic in which they were enmeshed, namely, the centrality and historical significance of the premodern and antimodern in the gendered configurations of religion and modernity. Modernity, as I see it, is not about linear progress or sudden ruptures but is rather a question of specific regional and transnational configurations with ideological valences and political locations. A conjunctural and shifting temporal marker, the term modernity could encode self-transforming individualisation, subversively egalitarian ideas of collectivity and self-determination as well as contrastive patriarchal/imperial discourses of domination. Inherently comparative, 'modernity' was established in relation to that which is not, less or too modern, i.e., as absence and excess.

If, following Jameson, modernity is also understood as 'a narrative category' (2002, 94), then the premodern and antimodern could be seen as contrastive figures of self-differentiation which refer, inconsistently, to the extinct, the residual or the coeval. The very naming of a 'premodern' was and remains an ideological exercise. After over a century of colonisation it would be problematic to simply identify all extant religious and patriarchal practices in India as premodern since some could be continuations from and before the 18th century while others entered different registers or were recast by state policies, laws, and labour markets in a colonial economy. Which features of social life were to be subsumed under the category of the premodern? What was to be selected as representative of a (desirable) premodern from a vast jumble of unchanged and changing patriarchal, religious, caste and other social practices in order to assemble an antimodern that could challenge western modernity? Since many definitions of a premodern were themselves made from an antimodern standpoint, the antimodern became - both formally and substantively - a pre-eminently modern staging of the premodern. Against the mystifications of a triumphal capitalist story of progress that obscured the simultaneous emergence of new predatory forms of domination and exploitation, the antimodern unease with capitalism could come armed with another set of mystifications - an ascriptive, moralistic discourse of cultural differentiation.

Since the antimodern was contextual, multi-sited and striated by its double lineage in Enlightenment ideals and collaborative indigenisms, it became a discursive space prone to pre-emptive resolutions and invaded by contradictions. Colonialism could be resisted in the name of universalism and particularist hierarchies 
could be (re)instated in the interests of self-differentiation. In critiques of the effects of capitalist expansion, the exploitation of labour and legal discrimination, Enlightenment ideals could be invoked in the claim to rights as 'British' subjects, but the ground of eligibility for rights could be sought in civilisational and gendered hierarchies which undermined universalism, foreclosed class struggle and feminist disturbance. A political modernity sought on the basis of an imagined ancient past and/or extant premodern ideas/practices of entitlement created sharp tensions between the theoretical universalism of rights and entitlement on civilisational grounds - which had gendered, casteist, and racial implications.

The discord between emancipatory Enlightenment universals and caste/ racial/civilisational differences was negotiated in several registers. In conservative colonial and indigenist patriarchal anti-western scripts, the antimodern could serve as an ideology of restraint for the colonised. At the same time, interrogation and contention catalysed by the disparity between Enlightenment ideals and the vivid denial of rights, the violent formation of colonial states and economic realities of imperialism could simultaneously reproduce and destabilise antimodern positions. Left and socialist critiques of capitalism and imperialism could also intersect with antimodern positions insofar as the term modernity was a synonym for the effects of the ongoing transitions to capitalism. Other affinities with socialism lay in the search for alternative lifestyles that could synchronise with a largely agrarian subcontinent and/or with communitarian alternatives to bourgeois or 'western' individualism.

The simultaneous production of a contrastive modernity and disaffection with the modern brought dissenters in the metropolis and colony into a peculiar proximity, and co-constituted a transnational arena across India and Britain. What were the registers of the antimodern and the qualities of the synthesis and antithesis of east and west in Besant's and Gandhi's writing in the early 20th century? The antimodern, with its distinct lineages, and unreconciled invocations of hegemonic and counterhegemonic authorities produced singular combinations and suggests an entry into how its proponents could have intensely agential and individualised religious repertoires, and, in self-contradictory fashion, also deindividualise others.

\section{Annie Besant's project}

Like the colonial state, several nationalist projects in India sought to appropriate the moral authority of altruism, reform and regeneration in order to legitimate self-government. Further, the quasi-orientalist diagnosis of India - as repository 
of usable 'feudal' modes and as subject of reform, religion and patriarchy as the most ancient and organising principles of Hindu society, religion as providing a compensatory area of 'autonomy', the true enlightenment of Indians lying in their own past traditions, and the special spirituality of women (read special powers for submitting to subjection) - structured such nationalist projects from the late 19th century. In this respect neither Besant nor Gandhi were original. The decline-and-rejuvenation narrative, an effect of textual transmission, was a settled authority supported by a spiritual east/materialist west binary that appeared in reformist tracts and print media; it paraded patriarchal features as marks of distinction from other religions/cultures, invoked an ancient golden age - Hindu, Vedic or Indian - that turned a zone of colonial extraction into a site for the production of symbolic value (Sangari 1999, xviii, xxix; Veer 2001, 49-50, 144).

Annie Besant purveys this old diagnosis through a personal 'rediscovery' of 'Hindu' antiquity and adds a parallel narrative of the decline of British aristocracy that played on contemporary fears of evolutionary regression. Some strands of Theosophy were formed at the crossroads of Indology, European Romanticism and Orientalism - which had in common the production of self-confirming knowledge - and combined the aggrandisement of Hindu or Aryan antiquity with certain Euro-American occultisms. In this syncretic, circulating and rapidly transnationalised religion, the idea of a universal brotherhood became more attractive because it could include women. A religion without a god and human yet spectral Masters (the 'Mahatmas' - native spiritual adepts), it rejected orthodox Christianity, looked to the east for spiritual guidance and had its own roster of 'native' interlocutors. ${ }^{3}$ Yet it saw itself as modern through the claim to science (Owen 2004, 34-35), and proposed a spiritually progressive evolutionism which made religion amenable to the laws of science. Through Theosophy, Besant channelled revitalising discourses and indigenist characterisations of Hinduism and upper-caste patriarchy into a more comparative and antimodern vocabulary a vocabulary that aggrandised a regimen of dharma, community, altruism and duty as opposed to the modern emphasis on rights, the individual, self-interest and the law.

Hindu Ideals (1904), composed from notes of lectures delivered at the Central Hindu College, Benares, addressed young Hindu male students and belongs to a transitional period, before Besant joined the Indian National Congress, in which she was immersed in occultism and busy smoothing the scandalous frauds and

3 Besant saw the promotion of the study of Aryan and other eastern literatures, religions and sciences as tenets of Theosophy (Beaumont 2010, 226). At this time, the study of oriental faiths was also seen to break down 'the exclusive pretensions of Christian dogma' (J. M. Wheeler, 'Hindu “Song celestial”', Our Corner, January 1886, in Miller 2013, 24). 
lawsuits left behind by Madame Blavatsky. In these lectures, she brahminised Theosophy and aligned it with a conservative antiwesternism and a notion of reluctant reform that was at once covertly assimilationist and blatantly revivalist. ${ }^{4}$ And the appeal of her ensemble lay precisely in this combination. She critiqued the 'west', concretised the prospect of cultural superiority and offered colonial indigenism as 'recognised', ratified and approved by western science and scholarship, extending the type of legitimation earlier offered by Max Müller into a politically programmatic notion of Hinduism. ${ }^{5}$ Like Müller, she endowed ancient Hinduism with a unified metaphysic and a tutelary, inspirational role vis a vis the west. Hindu Ideals also rehearsed the enabling dichotomy in the colonial semantics of non-interference: ancient Hinduism had survived in its 'distinctive polity', in the still-preserved injunctions of rishis, in its women and caste order, but it had also degenerated, needed succour and preservation by non-interventionist rulers (Besant 1904, 141, 143, 154-55). ${ }^{6}$ Further, Hindus were provided with the possibility of a synthesis of 'east' and 'west' through selective assimilation (ibid. 3-4) that could pose as a restoration of ancient Hindu glory - that is, a type of modernity that could be coded as a mere return to native 'wisdom', and a type of synthesis by which they could be modern, that is, as regenerated Hindus, but could simultaneously denounce modernity. In short, they could have it both ways.

In a schema analogous to J. G. Herder's romantic restorative ensemble in which each society was an irreducible, unique totality with a national soul and spirit, and the nationalist simply spoke for that spirit, Besant characterised 'Ideals' as nationally distinct 'essentials' rooted in the nature of a people (ibid. 5-10). However, in a peculiarly Theosophical twist, she gave a transnational itinerary to the soul and orchestrated the cycle of rebirth in relation to 'individual' national identities.

4 This section draws on Sangari 2004. Besant later represented the Theosophical Society as third in the great movements for the revival of religion in India after the Brahmo Samaj and the Arya Samaj with each marking 'successive developments of the national self-consciousness' (1925, 26, 32).

5 For Müller, who never visited the country, India supplied the 'missing links' in Europe's 'intellectual ancestry': 'We all come from the East - all that we value most has come from the East, and in going to the East [...] [a European] ought to feel that he is going to his "old home", full of memories' (1882, 6-7).

6 Besant instructed the British that they 'must learn to rule [India] according to its traditions' (Theosophy and Imperialism 1902, in Anderson 1994, 568) which, ironically, synchronised with Britain's paternalist phases of selective 'non-interference' in 'native' customs and religions in the presidencies under direct rule in 19th century India. On these phases, see Sangari 1999: xxvi, 105, 188-89; Veer 2001, 21, 113. 
Nations embodied special characteristics, and the Jivas - the souls which are ready to develop these characteristics are guided by karma to take birth in those nations. These characteristics will find their place in the Ideals of those nations.

(Besant 1904, 10)

Karma is a causal force for nations while reincarnation is a site for typification. The grouping of souls of one kind has significant implications for the caste order, marriage, and contraception (to which I will return).

Besant's diagrammatic construction of west and east, in practice only Britain and India, instituted a discourse of rights versus duties that sought to displace historical comparativism by a differentialist discourse of civilisational moralism. The modern west nurtured 'the lower mind [...] dealing with concrete objects, the reasoning, questioning, scientific mind'; it had formulated the free, self-reliant, solitary individual bearing rights locked in a (Rousseauvian) social contract for the protection of these rights into a powerful 'Ideal' of liberty and individual strength (ibid. 11-15). This ideal, assisted by a Christian religion 'given to help the western evolution', in turn spawned a host of (imitable) virtues: social service to the needy, charitable institutions, the public spirit of citizenship and patriotism, personal and social qualities ranging from self-respect to justice as well as martial virtues such as will, valour and energy - all of which had enabled England to colonise the world (ibid. 15-17)! Though Besant may not have intended this, the profile that emerges is of a Christianity allied to British nationalism and committed to producing disciplined citizens for an imperial state.

The Indian 'Ideal', 'embodied in one word, Dharma, Duty', flowed out of a religion that taught 'Unity of Existence' and a plan of society formulated by the rishis: it envisaged each person as embedded in an interdependent social order, born into obligations rather than freedom, upheld integration and 'the orderly distribution of social functions' through varnashram dharma - the different duties prescribed for each of the four castes (ibid. 18-20). While the western ideal stemmed from its history of industrialisation, the Indian ideal of the 'Man Dutiful' typically emerged from ancient religion and was the exact obverse of individualism. However, rights (constellated with western individualism, aggression and separatism) are said to be no different from duties (constellated with dharma, peace, unity), because 'each man obtains his rights when all around him discharge their several duties' (ibid. 20). The implication is paradoxical: the standpoint of rights is morally inferior to that of duties but duties encompass rights anyway, and in this Indian antiquity is modern and supersedes the modern.

In this non-contractual regime where duties double as rights, the absence of social contract not only characterises the relation of the individual to the state but covers all social relations and becomes, curiously, the foundation of obedient citizenship, state power, domestic and caste stability. Ethics proceed from 
the individual in the Christian west and from the transpersonal realm of 'social Dharma' in India, a dharma which is in accord with varna: thus 'the dharma of the shudra was to serve' (ibid. 20). The virtues that spring from the 'Ideal of Dharma' are based on 'a sense of obligation', which is to be discharged even if there is no reciprocity; wrong must be met with right even when the other party (king, husband, wife or son) is unworthy (ibid. 20-1, 23-24). In this non-retaliatory, non-western stance, lay the 'safety' of individual karma, the family and the state (ibid. 23-24).

Dharma thus appears, paradoxically, to be a premodern version of social contract that creates non-contractual social relations and frees India from the dangers raised by modern iterations of social contracts in the west. This was, in fact, to become a cardinal tenet of antimodernity which carried not only guarantees for the state but also profound patriarchal assurances. Besant drew on multiple legacies. She leaned on the deist, moderate tendencies within the Enlightenment which either sought to make it compatible with Christianity or were nervous about discarding religion as a guarantor of social stability as well as on conservative reactions to the Enlightenment (see Jacob 1981, 84, 263; Collier 1990, 93). By the end of the 19th century, the discourse of duty had been assimilated into a conservative bourgeois moralism impelled by unsuppressible fears of universal enfranchisement in Britain and in the colonies. Further, Besant's extension of duties to cover rights - rights that could not be claimed but only given to the other through the performance of one's duty (Besant 1904, 20) - and the characterisation of domestic relations as a privileged non-contractual site promised to safeguard patriarchies and suggests two overlapping rationales. These may have trickled down from the classic patriarchalism of European political theory (such as Robert Filmer's defense of patriarchal authority) which argued explicitly for a natural hierarchy of inequality. They may all have been gleaned from new theories of social contract which tacitly upheld patriarchal categories by placing the private-domestic domain outside the public-political and contractual realm. As Pateman shows, the social contract remained sexually ascriptive: social contract theorists saw men as civil equals but still represented the subjection of women as natural by defining women and the private domain in particularist ways (1988, 102, 104-07, 112-13). Besant's address too, in assuring male privilege, pushed against the individualisation of women and feminist attempts, including her own, to renegotiate this social contract through suffrage, married women's rights to property and better divorce laws. However, the address to Hindu men is double-edged since the description of all eastern social relations (and not those centred on women and the family alone) as bound by primordial obligations, threatens, ironically, to renew a Eurocentric and generalised feminisation of the east along the line of the internal fracture in the Enlightenment which 
had partitioned its egalitarian promise by excluding women. ${ }^{7}$ The spatial split between individual rights and social duties not only played into an imperial cartography of west and east but tended to undermine Besant's own earlier emphasis on the fact that obligations were an integral strand in the modern European discourse of citizenship and rights carried moral imperatives as well as implied correlative duties for individuals and citizens. ${ }^{8}$

In her description of contemporary changes, Besant tried to circumvent such a spatial split by reconnecting eastern duties and western rights; however, she could only do this by invoking different principles - that of a synthetic restoration of antiquity in the east and that of intelligent modernisation in the west. Whereas selflessness derived from dharma tends to dissolve the individual into the social body, the selflessness derived from a Christian or humanitarian ethic transcends the individual. The west was now approximating the east since 'modern scientific thought' and the discoveries of evolution had dispensed with the idea of society as 'an artificial contract'; it had learnt to recognise the essential organic unity of humanity and 'a sense of community' had given birth to 'Altruism' (Besant 1904, 25). This altruism, a triumph over selfish individualism, had led to 'co-operation instead of competition', the growth of 'public duty' and 'conscience', provided the poor with protection, social security, free education and services that limited their oppression (ibid. 26). Altruism or the 'Ideal of Duty' now stood higher than rights in the west. Unfortunately, because of 'the decay of spirituality', India was moving in the opposite direction: the 'Ideal of Duty' which once comprised the essential 'Dharma' of India had declined, the 'field of duty' had contracted to the familial (ibid. 27). Unlike the west, where they emerged from the individual who embodies rights, the wellspring of public duty and national unity in the east happened to be spirituality, it followed then that reviving spirituality would revive these as well.

While Besant's version thus retains some 19th century functions of altruism and philanthropy - as legitimising ideologies of the dominant classes in England and the colonial state in India as well as euphemisms for imperial expansion in general, ${ }^{9}$ it carries some materialist concerns from her socialist past. Prior to the

7 Though women were excluded in Enlightenment thought (Landes 1988, 204), the French Revolution was a key point of reference for feminists who saw themselves as 'retrieving the radical kernel within the Enlightenment project' (Felski 1995, 166).

8 Discussing these aspects of citizenship, Freeman notes that the Declaration of the Rights of Man and the Citizen in 1789 emphasised legal and inalienable, but not absolute, rights of individuals and closely associated these with duties of citizens/members of 'a social body' and obedience to the law (Freeman 1990, 172, 176, 178).

9 Altruism and philanthropy structured the entry of British middle-class women into the public domain in England and its colonies and, conditionally, offered a position of imperial dominance while meliorative charity was implicated in managing class antagonisms in Victorian England 
adoption of Theosophy, Besant had protested the exploitation of tenant farmers and labourers, organised trade unions and strikes, exposed the self-serving hypocrisy of Christian charity (1908, 304-05), and envisaged an evolutionary schema in which societies ascended from industrialisation to a non-competitive socialism (see Besterman 1934, 110-14, 116-18, 124-26). Now, however, altruism presents itself almost as an achieved socialism that also renders redundant Socialist agendas in Britain. ${ }^{10}$ While altruism fills the deficits of modernity in the west, it signifies the antimodern in India, acquires the power to chasten the modernity of the west and bring it nearer to the eastern ideal by joining rights with duties. Antimodernity becomes the vector of western self-reform qua 'easternisation' and such an easternised west becomes more fit to govern both its own class society and its colonies. She offers antimodernity to the west as an improved ideology of imperial expansion and as a renewed rationale for non-interference in Indian religions.

In a second and equally interesting move, antimodernity becomes the ideological correlate of India's passage to modernity with altruism functioning once again as a friendly conduit. The west approximates the ancient east through the discoveries of science, that is, through its very modernity. Antimodernity is thus a natural product of the expansive historical logic of western society and science. However, the east becomes like the contemporary west through rediscovery and restoration of its ancient polity and morals, that is, through a necessary antimodernity. Ideologically, this writes antimodernity into the very terms in which modernity can legitimately be adopted - modernity to the colonised must always come in disguise and disguised as their own earlier self. The accommodation of change whether as innovation, assimilation or imposition can be justified only if modernity is simultaneously disavowed. The very path to modernity is surreptitious and structured by a semantic of concealment while antimodernity becomes the name for screening or suppressing the several modern premises in which it was itself grounded. This also provided a method for recasting similarities between west and east into a discourse of cultural difference. If the west has similar values then it was because it had belatedly but correctly begun to approximate the east, if the east had the same values as the west, then they were its own to start with. Once synthesis was cast as a return, then any open assimilation of the modern because it was different (and therefore desirable) could (and still can)

(see Sangari 1999: xliii, xlix, 104, 173-74). In her educational enterprises in India, Besant too was implicated in these agential avenues.

10 Beaumont notes that the confluences between socialism, occultism, especially Theosophy, utopianism and evolutionism could dematerialise socialist discourse and render it 'half-mystic'. The utopian concept of a universal brotherhood allows Besant's socialist beliefs to be 'preserved' and 'mummified' inside her Theosophical faith (2010, 223-28). 
be derided as foolish imitation and crude derivation while covert assimilation was given the opportunity to pose as true indigenism. Effectively Besant offered antimodernity to Indians as a dual site of veiled collaboration and proclaimed autonomy.

The Indian paradigm of altruism that Besant projects as ideologically superior to the western and Christian is extracted from a strictly caste-divided, severely brahminical and patriarchal Hinduism, heavily dependent on the four prescribed ashramas or stages of life, sacrificial rituals and ceremonial practices, and extrapolated from the Smritis, Shastras, Ramayana and Mahabharata (1904, 30-33, 38-40, 47-49, 54-55, 58-60, 64-65, 70-72, 159-62). In fact, Besant participated in the scripturalisation and canonisation of the epics, and the colonial aggrandisement of the Manusmriti, a text that now combined the weight of ancient prescription with colonial power (see Sangari 1999, 314-16). In Hindu Ideals the prescriptive corpus of the Smritis or Dharmashastras, obsessed with hierarchy and segregation and claiming to draw its authority from the Vedas, is made to stand in a mutually confirmatory relation with the Ramayana, rather than one that is discrepant; both speak in one voice and the epic appears to be merely the popular adjunct and prevailing face of prescription - an illustration of the ideals of marriage and kingship (Besant 1904, 93-95, 125).

Besant had earlier opposed Judeo-Christian patriarchy as the underpinning of disempowering Victorian legal codes. ${ }^{11}$ She now valorises ancient Hinduism because it was patriarchal. Hindu Ideals presents the institution of Hindu marriage as the sacred bedrock of the social fabric that was not to be disturbed too much by reformers (ibid. 84), the patriarchal household as an enlightened yet despotic monarchy, the perfect householder as a potentate, a prototype of selfgovernance and a male mentor par excellence. The householder's own 'obedience to rightful authority' fits him to exercise authority over his domestic 'kingdom'; he orders and controls all in his home and, since he is a 'king', none may order or control him. He enfolds all castes in his person: the many household duties vary with each caste and are most onerous among the upper castes, yet every householder 'plays the part of each caste in his household' - as priest, protector, provider and servant of the household, he is a brahmin, kshatriya, vaishya and shudra! He is also the 'spiritual preceptor' of his wife (ibid. 66, 68, 75, 88, 92). The perfect wife - at once a friend and a reverential, obedient subject of her monarch husband - reigns over his household (ibid. 66, 93). The Hindu 'Ideal of

11 Besant attributed British women's legal disadvantage to biblical law and its interpretations which treated women as social and sexual property of fathers and husbands, and denied women 'the inalienable right' over their own persons without giving a wife equivalent property rights over the husband (Blyth 2009, 125, 130-33). 
Marriage' was based on the complementarity of sexes proclaimed in the Shastras, a non-antagonist non-competitive relation and not on separate rights of men and women as in the west (ibid. 85-86). In an earlier essay, 'Womanhood', Besant seeks to return Indian women to their own 'ancestral custom' (1900, 272, 278), asserting that anything which 'separates one sex from the other in life or interest or brings them into competition or rivalry' is fatal to the 'progress of the race' and upward evolution. ${ }^{12}$

In contemporary India, Hindu women were a homogenous and exceptional 'type', still naturally innocent, embodied the not-yet-extinct premodern, and had to be protected from the west. ${ }^{13}$ Since men had become 'materialistic', Hindu dharma had found its 'refuge in the hearts of its women, a sure temple whence it may never be driven' (ibid. 92-93). While women are guardians of 'Hindu dharma and the Hindu home' (ibid. 110), a dharma laden with patriarchal normativity, Hinduism is disconnected from nearly all patriarchal arrangements through familiar exculpatory moves - its own intrinsic superiority, eternal modernity, degradation and fall caused by later textual interpolation and Muslim conquest (ibid. 86-91, 99-100). In Besant's euphemistic interpretation, ancient Hinduism was not misogynist as Christianity was, while Hinduism's superiority to Christianity lay in its refusal to make any distinction between 'the sacred and secular' (ibid. 59).

Besant's antimodern discourse has a transparent class location. Her unease with 'democracy' in the west and eulogy of caste rest on an explicit admiration for hierarchy described as 'Aristocracy or the Rule of the Best' (ibid. 113-14), and a thinly veiled loathing for class mobility in Britain. An 'uncultivated' butcher or salesman who manages by dint of wealth to enter the gentry is described as having a 'Shudra body', 'Shudra manners', a 'Shudra Ego' and unfit to be 'a leader of society' (ibid. 157-58). For her, varna unlike class was the foundation of a non-competitive fourfold order, each caste comprising a distinct and immutable 'class' based on hereditary occupation (with shudras providing the 'broad basis

12 Here Besant is close to the socialist eugenicist, Karl Pearson who argued in 'The Woman Question' (1885) that scientific arguments about the good of the 'race' must always trump abstract reflections on women's individual rights: 'We have first to settle [...] what would be the effects of women's emancipation on her function of race-reproduction, before we can talk about her "rights", which are, after all, only a vague description of what may be the fittest position for her, the sphere of her maximum usefulness in the developed society of the future' (in Miller 2009, 249). The socialist investment in anti-individualism for a greater collective good could engender antifeminist arguments (see Miller ibid.).

13 In lectures given in 1897 and 1903, Besant said 'Leave the Hindu woman untouched by Western thought [...] We [the English] have women enough who are brilliantly intellectual and competent; let us leave unmarred the one type which is the incarnation of spiritual beauty. The world cannot afford to lose the pure, lofty, tender, and yet strong, type of Hindu womanhood' (1942, 546-47). 
of the national pyramid'), and a useful restriction on social mobility (ibid. 135). Thus there was no merit in contemporary India 'producing a bad copy of western forms and methods' and sinking into the very 'whirlpool from which the West is endeavouring to escape' (ibid. 137). Even the west was beginning to realise the value of caste - a 'social stability of form answering to the inner stability of spirit' - and of birth as a 'surer and more dignified foundation for social order' than wealth (ibid. 157). Her claim resonated with conservative European interpretations of the caste system (she cites Auguste Comte) as a sensible form of social organisation which had originated in racial division and the beneficent conquest of inferior natives by culturally superior Aryans - the ancestors of both contemporary Hindus and the British. ${ }^{14}$

Varnashram dharma as the image of a hierarchical society that was divinely ordained but maintained by law had already come to provide a space where the nostalgias of anti-industrial, romantic and conservative organicisms could effortlessly rationalise, blend or ally with Indian upper-caste conceits and interests. ${ }^{15}$ Besant's assimilation of caste to race coincided with the racialisation of caste in turn-of-century India, most infamously in H. H. Risley's anthropometry which fused the social and the biological (Samarendra 2010, 51-58), and defined the caste system as 'a community of race' (L. Gandhi 2014, 68-69). For Besant, caste is a system that fixes the division of labour and generates duties, national essences, and characteristics. What is unusual in Hindu Ideals is the conserving function of reincarnation through which the soul climbs on the caste ladder and ensures the reproduction of 'national Ideals'. The 'four stages in the long pilgrimage of the soul [which] are maintained in the four castes, the youth, prime, maturity and old age of the Jivatma' still exist despite foreign conquests: India could only preserve her 'racial characteristics' because of the 'strong barrier of caste' (Besant 1904, 154-55).

In earlier lectures collected in Ancient Ideals in Modern Life, Besant nominates the fourfold caste order - non-conflictual, orderly and progressive - as the chief reason for India's stability and explicitly binds it to 'the path to Evolution along which a human soul develops' (1901, 73-78). In successive births, 'the soul passes from one to another [caste], according to the qualities it has developed [and] the actions it has performed' (ibid. 79). The soul may rise or sink in this spiritual neo-Darwinism of individual and collective ascent and descent via reincarnation. Upward mobility increased responsibilities (especially of brahmins) since varna

14 On the locations of Indian and British Orientalist Aryanisms, which come together in Besant, see Veer 2001, 76, 143-44.

15 On the, often Orientalist, European fascination with supposedly 'non-exploitative and non-contradictory hierarchy' obtaining in 'Aryan’ India, see Kaiwar 2015, 110-12, 125. 
was not 'a system of rights claimed by a caste, but a system of duties imposed on a caste; the higher the caste, the heavier the duties' (ibid. 79). 'Heredity' supports status quo by playing a crucial role in 'providing suitable physical bodies to suit each type of subtle bodies (Sukshma Sharira)' (ibid. 81). Yet the caste order too has degenerated because it multiplied and subdivided, 'less evolved souls came into Indian bodies [...] and were no longer able to fulfil the dharma of the caste in which they were born' (ibid. 84).

The antimodern unfolds as an antidemocratic sign of cohesion, unity, racialised evolution, and restoration of individual (husband) and collective (caste) authority. The upward social mobility, strong workers' and women's organisations make Britain an awkward candidate for a paternalist restorative project; India, despite the fall of men, is more opportune because of the vaunted continuity of womanhood and varna. Ironically, the Victorianisms Besant reproduces or transmutes into an antimodern vocabulary and transposes to India were already severally mediated by the transactions of empire: as for instance, the anxiety about sources of spiritual and moral authority, the resolutions domestic ideologies offered for conflicts between paternalism and open competition, the domestic world as replicating social order and yet capable of transforming it, the detachment of morality from economic imperatives and women's economic deprivation as a basis for their especial moral authority as well as the home as a sanctified source of altruistic emotions that could (even should) replace Christian solace.

\section{Mohandas Gandhi's project}

As a set of pre-emptive resolutions, the antimodern aligns smoothly with empire in Besant. The contradictions are more evident in Gandhi. In South Africa, his main concerns were the status of Indians as equal citizens of empire and protection against racial discrimination (Habib 2011, 3). Faisal Devji notes that the Indian community in South Africa was 'shaped entirely by capitalist relations, whether of commerce, service or labour, and had no dealings with premodern forms of possession or production'; therefore, unlike in India, rights could be claimed more directly without invoking the safeguards or privileges of caste and religion $(2012,50)$. Yet, as Gandhi found, the 'rights' promised to 'Indian subjects' by Queen Victoria's proclamation in 1858 were not portable (Lelyveld 2012, 11), its liberal principles were not upheld. Visiting London as an increasingly disillusioned petitioner in deputations on behalf of Indians in South Africa, he wrote: 'The only possible justification for holding together the different communities of the Empire under the same Sovereignty is the fact of elementary equality' (Gandhi 
1958-1982, 9, 516). As he travelled between India, London and South Africa, colonialism seemed at once more dichotomous - a polarity of west and east - and more unified since capitalism was becoming ubiquitous. The colonies as sites of extraction stood in sharp contrast to the metropole as a venue of consumption.

Some strands in Hind Swaraj (a dialogue between a persuasive Editor and a Reader) noticeably approximate Besant. Gandhi consciously excludes European dissenters and the many Englishmen who desire Home rule for India from the 'west' (Gandhi 2015, 17), but makes a starker opposition between India and 'modern civilisation' in England (ibid. 41-42), grants less to the west on the counts of science, morality and religion, and refuses to turn India into 'Englistan' (ibid. 27). Yet, beneath the hyperbolic polarisation of sovereign and subject, both west and east are subjugated by a subsuming entity, a structuring force that determines the 'condition' of England, and through it, of India. He blames not the 'English people' but a destructive 'modern civilisation' not more than half a century old - 'a civilisation only in name' - 'under [which] the nations of Europe are becoming degraded' (ibid. 32, 34). He opposes a mode of conduct (named western civilisation) resting on force, colonial expropriation, and the desire of the British to 'convert the whole world into a vast market for their goods' (ibid. 40): the destruction of local industry and expansion of markets, pendant on speed and technological innovations, were impoverishing India. This flat indictment of colonial expansion, industrial capital, the exploitation of wage labour in colonies and metropole, and the obsession with profit is not too distant from Marx's more dialectical critique of the expansion of markets, the destruction of 'national industries,' and forcible introduction to all nations of 'what it [the bourgeoisie] calls civilisation', i.e. the 'bourgeois mode of production' which makes the 'East' dependent on the 'West' (Marx and Engels 1978, 476-77). Though Gandhi's critique is blurred by an overblown antithesis of east and west, clearly Britain is controlled by a modern civilisation much larger and more powerful than itself and India is being restructured by the same modalities. Despite the asymmetry of power, east and west are aligned in that both are governed by the apparatus of capitalism and the drive for accumulation. The English are subject to capitalism and Indians are subject to a subjected nation.

At the same time, a tension between universal rights within empire and the civilisational grounds for claiming them is apparent in Hind Swaraj. Gandhi's campaigns for rights in South Africa were allied to a notion of the special entitlement of Indians as 'British subjects', but did not escape the racial and civilisational hierarchies instituted by colonisation, and he limited his constituency by fighting white racism against Indians but not Africans (Gandhi 1958-1982, 1, 281; Gandhi 1958-1982, 6, 213; Skaria 2016, 40; Desai and Vahed 2016, 42-44). In Hind Swaraj, however, economic and cultural arguments eclipse the loyalism he had 
invoked earlier. Further, the semantic accretion within duties and rights allows these twinned concepts to move between role-bound entitlements and a universalist language of rights - both terms straddle ongoing political transitions and acquire subversive connotations.

Many of the east-west antitheses in Hind Swaraj rest on morality versus immorality, faith versus irreligion, spiritual laws versus the laws of matter, a noncontractual dharma resting on a non-retaliatory ethic versus contractual norms. ${ }^{16}$ In contrast to Besant's views, dharma has a wider semantic range. As Parel (2015, xxi, lxi, xc, 90), Skaria $(2016,42)$ and $\operatorname{Kumar}(2015,89)$ show, it can index duty, natural moral law, an injunction to the moral law, the pursuit of the welfare of the soul, religion as ethics, religion as sect (e.g. Hindu and Muslim), niti (ethics) and ethical integrity. Or dharma can be the opposite of adharma, i.e. irreligion (Gandhi 2015, 36). Parel's argument that Gandhi 'redefines the scope of dharma to include notions of citizenship, equality, liberty, fraternity and mutual assistance' and 'a civic humanism' may seem stretched (Parel 2015, xxviii); however, dharma is not credal - that is, confined to a single set of religious beliefs - and extracting it from the solely spiritual, Gandhi repositions it in a secular terrain of civic virtue.

Gandhi seems to duplicate Besant's assertion of the superiority of duty over the discourse of rights as well as the equivalence of duty and rights. However, he makes a distinction between duty, farajj, and religion, dharma (see Parel 2015, 90). Duty (farajj in Gujarati, from Urdu farz, Persian origin) and rights (hako in Gujarati, from Urdu haq, Arabic origin) can be 'premodern' and 'modern' signifiers, i.e. they can identify colonial subjecthood with premodern hierarchies as well as indicate the rights of proto-national citizenship. Farz denotes a set of concrete familial and social duties and responsibilities ordained by a person's role as well as a religious duty. The Reader's first concern in Hind Swaraj, shared by the Editor, is the demand for rights - hako - in India and South Africa (Gandhi 2015, 13; see Skaria 2016, 290). Haq can be a compressed term for both entitlement and rights. Entitlements flowed from occupational, familial, social and labour relations. Extra-legal as a social and relational term, haq becomes a legal term where the horizon of legal rights is the sovereign colonial state. Further, because it also denotes that which is just, haq can occupy a non-hierarchical ground of customary reciprocity or work to mitigate social and political hierarchy through the expectation of reciprocity. The kinship or interdependence implied in the two-way flow between farz and haq in extant northern and western Indian idioms

16 'The tendency of Indian civilisation is to elevate the moral being, that of Western civilisation to propagate immorality. The latter is godless, the former is based on a belief in God' (Gandhi 2015, 69). 
(which were neither peculiarly Hindu nor ancient), is not clear in Gandhi's English version of Hind Swaraj since rights and duties have a different linguistic tenor. Haq and farz flow from a place-bound terrain of specific entitlements for each person and require fulfilment of a role in order to gather its privileges. However, if rights flow from the place-less universalism attributed to a 'liberal' empire, everyone can have the same rights. Farz and haq, as embedded in familial and social relations, can be owed to those below and above and be claimed vertically or laterally; liberal rights, and even $h a q$ as rights, are only vertical, addressed to and claimed from the state. Finally, haq also means truth - and this range from truth to rights allows for religious, secular and political usages.

In his struggle in South Africa, Gandhi assumed a direct passage from an entitling performance of duty to legal rights for Indians. He believed that if they were loyal and did their 'duty' as British subjects 'rights' would 'follow' (Gandhi 19581982, 7, 397 in Desai and Vahed 2016, 125). ${ }^{17}$ In Hind Swaraj, the foregrounding of passive resistance to British laws redirects the interdependence and sequence of duties and rights towards the state. Passive resistance is defined as 'a method of securing rights by personal suffering [...] the reverse of resistance by arms' (Gandhi $2015,88)$, i.e. securing rights from the government by non-violent means also outlines the proper role of a just state. Obedience of unjust laws thus becomes contrary to dharma, which Parel annotates here as ethics (2015, 90-91). The subject/citizento-be is duty-bound to be disloyal and disobedient to the laws of an extractive, coercive or evil state (Gandhi 2015, 112,116), and by performing this duty becomes morally superior to the state. Duty functions as a broad critique of tyranny and sovereignty which applies to contemporary Indian kings and princes as much as to British rule (Gandhi 2015, 74-75, 92-93). In emphasising the duty of rulers, Gandhi attempts to hold the colonial state to its own promises, liberal principles and professed altruism - the self-imposed task of ruling/serving without reward.

[...] real rights are a result of the performance of duty; these rights they [the English] have not obtained. We, therefore have before us in England the farce of everybody wanting and insisting on his rights, nobody thinking of his duty. And, where everybody wants rights, who shall give them to whom?

(ibid. 79-80)

If rights flowing from duties are read through $h a q$ and farz, their meaning exceeds mere equivalence. Farz and $h a q$ can only be sutured by a conditional reciprocity and

17 In 1906, Gandhi justified his organisation of an Indian ambulance corps during the British suppression of the Zulu rebellion on the ground that if Indians 'claimed rights of citizenship, they were bound to take their natural share in the responsibilities that such rights carried with them' (Gandhi 1958-1982, 5, 326). At the same time, he argued that the British Empire could not hold its position by 'unfair treatment of its loyal subjects' (ibid 5,326). 
duty may be the means of acquiring rights. Further, if rights flow from performed civic and social duties, the power and centrality of the state is partially displaced. The state must do its duty to earn its right to sovereignty: an unjust state not doing its duty can have no rights over its subjects. ${ }^{18}$ Loyalty too becomes conditional.

Gandhi, like Besant, castigated imitation of the west and its political institutions, saw varna as locus of social stability, a weapon against materialism and 'life-corroding competition', and equated 'moral fibre' with continuity (Gandhi 2015, 66-67). Although connections between white racism and the practice of untouchability began to emerge in South Africa and he was to modify his views on caste in the 1930s (Lelyveld 2012, 25, 42, 60-61, 132), quasi-Besantian formulations recur over many years. For instance, in 1920 he represented caste and class as simply different modes of social organisation evolved in India and Europe; both had 'produced certain evils' but caste had helped more than class 'to conserve certain social virtues'. The caste system was non-hierarchical and not based on 'distinctions of wealth and possessions': it was an 'extension of the principle of the family' and similarly 'governed by blood and heredity'. Even if the 'western doctrine' of milieu is accepted, 'milieu can be preserved and developed more through caste than through class [...] It is the best possible adjustment of social stability and progress' (Gandhi 2015, 286-87). Like Hindu Ideals, Hind Swaraj combines transhistorical continuity with restoration: 'India is still, somehow or other, sound at the foundation' and modern civilisation has not yet reached all parts of the country (ibid. 64, 68, 70), while its fall is a result of the temptations of modern civilisation that accompany colonisation and are turning Indians away from god as well as from the antimaterialistic tenets of all their religions. ${ }^{19}$ Here, continuity can also be read to mean that colonial capitalism was not yet singly or fully determining and had not rationalised or homogenised those regions, which had little functional importance for it.

Gandhi's argument for civilisational superiority, unlike Besant, includes a plurality of religions. He condemns the British policy of divide and rule, distances the anti-Muslim bias encoded in indigenist decline-and-restoration narratives by laying out a mixed older history of conflict and peace as well as rationales for Hindu-Muslim amity (ibid. 50-55), rejects an organic or homogenous view of nationalism, repeatedly refers to India as multi-religious, refuses the idea that any one religion could comprise a nation, and reminds the British of their duty to

18 Here too Gandhi departs from Besant. In her Indian 'Ideal of Duty', 'duty must be done even to the undutiful' (1904, 23).

19 Consumerist industrialisation is said to lack dharma and morality; it is 'Satanic' according to the teaching of prophet Muhamed and Kaliyug according to Hinduism (Gandhi 2015, 34--7). 
protect all faiths. ${ }^{20}$ Further, neither civilisation nor satyagraha (truth-force) follow the laws of evolution. Civilisation understood as 'good conduct which points out [...] the path of duty' (ibid. 65) could be transhistorical while Gandhi's concept of truth-force, being more than moral, belongs to 'the ontological order of being' (Kumar 2015, 63).

On Besantian lines, this civilisation too is said to flow from the 'due deliberation' of 'our ancestors' and 'forefathers' with their principled respect for rishis and fakirs:

They saw that kings and their swords were inferior to [the] sword of ethics, and they, therefore, held the sovereigns of the earth to be inferior to the Rishis and the Fakirs. A nation with a constitution like this is fitter to teach others than to learn from others.

(Gandhi 2015, 67, my italics)

In Hindu Ideals, Besant's rishis were composite characters: at once 'divine' and 'superhuman men', objects of ritual-centred worship and 'legislators' who had built the 'stately edifice' of caste as well as India's 'social and religious polity', still efficiently preserved by Hinduism; they enforced righteousness through ' $d a n d a$ ' (punishment) but also 'transcended humanity in evolution, by long service, by sacrifice, by tapas [concentrated spiritual exercise and austere self-denial]' (Besant 1904, 29, 70, 113, 119-20, 143, 145, 156). In Hind Swaraj, Gandhi's location of the true Indian tradition as ascetic and renunciatory is partly affiliated to Besant's foundational rishi but diverges in significant ways. First, all religions are based on ethical principles (he objects to British rule because it is unChristian). Hinduism, Islam, Zoroastrianism have in common 'that religion which underlies all religions' (2015, 41). Skaria annotates this as 'the unrepresentable and inexpressible kernel that constitutes the condition of possibility for any religion as well as any conception of the ethical' i.e. satyagraha $(2016,15)$. As a self-governing country India was to be ethico-religious in spirit but not in the literal sense of representing any particular religious denomination. Second, the Indian ascetic tradition which includes fakirs (a term used for Muslim mendicants), signals a non-sectarian view of ancient and medieval ascetics and, potentially, an inclusive dharma. Predicated on a personal struggle for self-mastery and linked to the project of self-rule and public service, ascetism fell into a self-sacrificing altruistic schema that functioned as a politically effective source of extra-political authority and legitimation. His invocation of the

20 Gandhi argued that 'one nationality' and 'one religion' are not synonymous anywhere in the world; Hindus, Muslims, Parsis and Christians 'who have made India their country' are 'fellow countrymen' and will have to live in unity if only in their own interest (Gandhi 2015, 50-51). Gandhi's emphasis on Hindu-Muslim unity was forged in South Africa (see for instance, Hunt 1993, 51; Lelyveld 2012, 14-15; Natarajan 2013, 164-65). 
'sword of ethics' diminishes the fear and power of merely political sovereignty (see L. Gandhi 2014, 20). Ascetism becomes a cross-religious resource from which to derive generalisable civic virtues and is intended as a weapon for the social reform of Indians and the British. Third, while as pre-determined by ancestral authority and calculation as Besant's, Gandhi's version of ancient civilisation was more programmatically based on anti-materialistic principles and austerity: it had set limits on wants and 'indulgences', disciplined passions, proscribed 'luxuries and pleasures', restricted technology and urbanisation, reduced competition, kept courts, lawyers and doctors 'within bounds', eschewed technological innovation and maintained the moral force of people through manual labour (2015, 66-67). 'Our ancestors' can be read as limit, prophecy, injunction, and example. They seem to be precapitalist and presciently anticapitalist, and function as a reminder that industrial capitalism is a chosen and thus reversible trajectory. The ancient limit must be recalled in order to restrain the hubris of a limitless modern. Varna and womanhood become performative, enacting - in perpetuity - the constraint of the limit.

Gandhi's critique of capitalism is bolstered by an inflation of the spiritual register but he diverges from Besant in construing civilisational virtues as unassimilable by a capitalist west. Rather the interlocking of anticapitalism and cultural differentiation works to double the claim to an intractability which also redefines nationalist struggle and British presence in India. While Gandhi still retained the Moderate's faith in British Empire, the project of Indian self-rule had to differ from as well as usurp the moral authority of the colonial state. A relation of mutual benefit with the British could be made if 'the root' of this relationship was 'sunk in religious soil', for this they must search their own Christian scriptures. Indian civilisation being the superior one, the British must abandon modernity, live in the same manner as Indians, do nothing that was 'contrary to our religions' - Hinduism and Islam, and desist from commercial benefit and drain of wealth (ibid. 112-13). Reversing the direction of colonial universalising projects, he imagines a moralised, that is, Indianised and non-capitalist British Empire as more fit to govern India (ibid. 71).

In some sense then, Hindu Ideals and Hind Swaraj are imbricated in complex and continuous interchanges within the British Empire, and can be read as related and intersecting texts making distinct correlations between a reformed empire and antimodernity. In Hind Swaraj the antimodern is a sign of civilisational longevity, a mode of cultural self-differentiation, an anticapitalist argument for austerity and autonomy from the 'west', and a means for accruing nationalist authority. Yet it is an unstable sign since Gandhi's own, equally compelling, confluences were with liberal, egalitarian and secular tendencies. His notable departures came in the growing and insistent refusal to restrict the centrality of religion to Hinduism by including all religions, the attempt to relocate cultural exceptionalism in good conduct and a multi-religious society rather than in a unique Hinduism. 


\section{The womanhood project or disentangling the marriage knot}

From the late 19th century marriage was a social and symbolic question in Britain and India. The comparative hierarchical ranking of sexual behaviour and marriage practices in colonial anthropology turned monogamous and regulatory/ normative marriage into a marker of civilizational status (as is visible in Besant). Regulatory marriage was a recognised site of constraint and deindividualisation for women. In British and Indian conservative opinion, it was openly defended as a boundary marker which secured the ground for religion and nationalism, race regeneration and caste (jati) endogamy, racial superiority and national reproduction, the stable progress of evolution and empire. Marriage, then, was a matrix for the reproduction of multiple inequalities and not merely a compact between two individuals. At the same time, intense critiques of restrictive and oppressive marriage practices were mounted from different positions by British socialists, British and Indian feminists, Indian higher and lower caste reformers, while British libertarian feminists argued for marriage resistance or free love. Even as the limitations of regulatory marriage in Britain and India were under scrutiny, respectable (monogamous) marriage was still seen as a precondition for women claiming a place in the public sphere and/or full citizenship. Further, with proletarianisation and the bonded/indentured labour market, marriage and family structures were in a state of flux which coincided neither with higher caste patriarchal practices in India nor with Victorian ideals of companionate marriage. Women were entering the work force in Britain and India as they industrialised, families were separated through forced migration in the colonial labour economy, indenture was creating non-endogamous marriages and non-marital households, and patriarchal practices were being challenged and reformulated in contexts of caste mobility, class formation, or consolidation.

Indian marriages simmered and then erupted as a political issue in South Africa. In 1906 Gandhi had protested against the requirement of separate permits for wives travelling with their husbands and posited Indian couples as a single unit (see Natarajan 2013, 133-34). In 1913 Hindu, Muslim, and Zoroastrian marriages were invalidated in South African law which would from that point, recognise only monogamous weddings performed by judges, state officials, and Christian clerics. This meant that in the eyes of the law all non-Christian Indian wives were living out of wedlock and their children were illegitimate (Lelyveld 2012, 107). Further, the state refused to classify any Hindu or Muslim marriage as monogamous since the rites were performed in India, a country which permitted polygamous marriages (Desai and Vahed 2016, 172-74). Gandhi said that Indian 
wives were being 'treated as concubines' (Gandhi 1958-1982, 13, 61 in Natarajan 2013, 133). Many Indian women from different regions, religions and castes jointly protested this derecognition of their legal status as wives and the campaign, which fused the claim to rights with cultural or religious self-differentiation, acquired a defensively nationalist tenor.

After Gandhi returned to India, in speeches and writing till the 1920s, womanhood became an embodiment of an indigenist principle that was meant to challenge the very foundations upon which colonial authority, western materialism and degrading indentured labour were seen to be based. The indigenist valorisation of non-competitive, non-contractual social relations that legitimated conventional patriarchal and caste-based divisions of domestic and reproductive labour thus remained more or less intact. ${ }^{21}$ At the same time, within Gandhi's project, the notion of womanhood became a ground for desired social change including the abolition of indenture, the backbone of swadeshi (national self-reliance in manufacture and institutions) as an anticolonial gesture, an anticapitalist move towards economic self-sufficiency, and the space within which women's public participation was to be determined. The description of womanhood was not a displaced site for the issues of the freedom struggle. The already significant and material question of patriarchal practices was for him also wrapped into spiritual self-purification, agential questions to be resolved in relation to the 'west', and was overdetermined by the pursuit of the common essence beneath all religions.

Here I focus on the identification of women and sacralised marriage with social stability and the bedrock of religion through which marriage could become a site of deindividualisation. The non-violence Gandhi attributed to Indian women corresponded to the transhistorical essence of all religions (ahimsa, active love and compassion). Yet in the singular civilisational genealogy of womanhood and the epic lineage ascribed to the new companionate model of marriage, Gandhi is close to Besant's project in Hindu Ideals. She had extracted complementarity, a quasi-bourgeois conjugality with its subordinate 'companions', from 'antiquity', that is, the Shastras and epics. Rama and Sita were 'shining examples' of the 'Hindu Ideal of Marriage' while Savitri, Damayanti and Shakuntala were lesser examples of wifely fidelity (Besant 1904, 93-96). Gandhi's model too was premised on antiquity, the same canon, similar notions of intact womanhood and fallen men, and the insistent separation in Hind Swaraj of 'ancient civilisation' from the 'defects' of contemporary marriage practices (Gandhi 2015, 69). This

21 Gandhi's idealisation of women as morally superior subjects, his positions on chastity, sexuality and celibacy and marginal alteration of domestic roles have been thoroughly critiqued. See review in Hardiman 2013, 1715-981. 
could tacitly make Indian women coeval with ancient 'Hinduism' since their power, strength and moral courage were said to derive from a unique 'spiritual background', to be 'totally different' from women of other countries and also capable of compensating for the contemporary lack of male altruism (Gandhi 1950, 50; Gandhi 1958-1982, 87, 294). The ideal woman Gandhi wants to create depends on epic exemplars. She will be 'pure, firm and self-controlled' like Sita, Draupadi and Damyanti, and her 'words will have the same authority as the Shastras' and be respected like those of her 'prototypes of yore' (Gandhi 1943, 19). She herself becomes the unwritten and embodied text of tradition. However, women are also seen as an inclusive entity and dharma as a cross-religious concept that holds a country together:

'I know that in all communities, Hindus, Muslims, Parsis, and others, it is the women who preserve dharma. The day they forsake dharma, it will be destroyed. Our shastras say that a country in which the king and the women have abandoned dharma perishes.' (Gandhi 1988, 58)

It was the regulatory, more than the explanatory or compensatory capacities of religious systems that had been at stake in the vociferous identification of women with Hinduism by 19th century reformers, and in some respects dharma for Gandhi too was a principle of restraint and restriction. Marriage in turn was the posited as the 'fence' that protects religion/dharma, analogous to its disciplinary powers, and like dharma, rested on 'the law of restraint' and restriction: women thus were 'the apple of discord where the marriage bond' was 'loose' (Gandhi 1943, 155). Yet political self-determination and cultural self-differentiation being intertwined, Gandhi had to locate women at once as immutable and plastic, passive and active. He oscillated between seeing women as essential selves and selves that could be refashioned, as fixed repositories and instruments of desired change (Gandhi 1958-1982, 14, 86-87; ibid., 54, 184).

Besant had placed sacramental marriage at the heart of a regulatory, patriarchal, sacrificial, national complex that could be maintained only if the conjugal relation was represented to women as spiritual rather than as carnal. ${ }^{22}$ Marriage was not only situated in a similar complex for Gandhi but locked into altruism, civic and political duty, and a polyvalent ascetism which could be repressive or a

22 'Beware how you undermine in the hearts of Indian women the sacredness of marriage and the glory of the life of sacrifice. High have they held their Ideals through innumerable ages, and cherished love of husband as a spiritual force, and not simply as an earthly joy. Beware how you represent to them carnal pleasures as more alluring than the spiritual, and the life of ease and delight as more attractive than the life of self-obligation and sacrifice. If India is to be saved by her women, it will not be by women whose ideals are lowered' (Besant 1904, 109-10). 
vector for individualisation. At one level, this was the corollary of a non-violent reformism in which the suppression and sublimation of sexuality seemed so central to conducting a public and political life of service, social work, passive resistance and dutiful disobedience that he virtually platonised marriage. Since he saw sexuality as a literal and metaphorical emblem of human vulnerability, self-control also became a measure of human aspiration, a part of the process of individual and national self-definition, analogous to swaraj (literally rule over one's self) and applied equally to both sexes. Hind Swaraj classifies sexuality as 'an animal indulgence', recommends chastity as a mental discipline for all men, forbids all but procreative sexuality for married couples, wants perfect chastity for a married man if he is a 'passive resister' but postpones a discussion of the consent or 'rights' of wives (Gandhi 2015, 95). The investment in a curative ascetism led Gandhi to typecast women's nature as a type of asexual purity: she was not 'prey to sexual desire to the same extent as man' and more capable of self-restraint $(2010,105)$. Since ascetism for him was a largely non-reclusive, non-renunciatory practice of self-control and non-possession, it did not contradict women's domestic roles. The daily domestic sacrifices of women could be made congruent with the sage's tapasya (ascetic self-denial) and coincided with the literal identification of household labour with piety in popular prescriptive literature (see Sangari 1999, 344-49).

For Gandhi, marriage also became a pre-eminently public institution; he resisted the domestic enclosure of conjugality, refused to corral marriage into a private sphere or import the shield of privacy that accompanied liberal individualism and bourgeois familial ideologies. The domestic was to be a transparent adjunct of the public. Domestic life and sexuality were to be integrated with and regulated by public duty, and women could regulate male sexuality if they sublimated their own (Gandhi 1943, 15-17). Abstinence could transform marriage into an altruistic institution. The bestowed and claimed virtue of English women had provided a moral right to rule. Gandhi's extended ascription of virtue, moral power, sexual restraint and altruism to Indian women and marriage as part of the claim to self-rule went further. Under nationalist imperatives, altruism overlapped with ahimsa in inculcating ideals of public service and finding a principle of unity that would bond diverse groups. It also served as a platform from which to argue for the abbreviation of British rule.

Gandhi's preoccupation with abstinence was not dissimilar from earlier Victorian social purity campaigns and some contemporary middle-class feminists in England who also preferred abstinence over birth control as giving women more control over their sexuality, a degree of sexual autonomy within marriage, and protecting them from the transmission of venereal disease by profligate husbands. For theosophists, however, contraception interrupted the orderly reproduction of 
race, and by implication, caste. Madame Blavatsky insisted on self-restraint and celibacy since birth control interfered with the laws of reincarnation by reducing the number of bodies to which reincarnated souls must have access (Viswanathan 1998, 196; Owen 2004, 98-99). After adopting Theosophy, Besant withdrew her writing advocating birth-control. She described sexual love as a source of intellectual slavery and human degradation; argued that self-control and denial in marriage rather than contraception would assist upward movement on the evolutionary ladder of rebirth; and recommended 'restriction of the sexual relation for the perpetuation of the race' (Besant 1908, 243; Besterman 1934, 91-94). Later, in the context of child marriage and adolescent sexuality, Gandhi too argued for a restrained procreative sexuality on similar ground: the 'transgression of those limits imperils womankind, emasculates the race, induces disease' (2010, 62). Non-procreative sexuality is also addressed as a symptom of western modernity. Gandhi's notion of celibacy affirmed orthodox ideas of semen preservation while Besant felt that the 'animal' sexual passion and cravings of men and women had gone beyond 'natural limits' both inside and outside 'the marital relation' in 'civilised countries' (1908, 242).

The selflessness attributed to Indian women combined with a political will to change could easily arc into the nurturing, selfless Victorian woman reforming both herself and the world - a figure who was at the deep centre of nationalist class consolidations in imperial Britain. However, Gandhi's notions of full and partial celibacy offered an ideational and everyday form of intractability which moved towards the formation of a new sociality that cut through religious and patriarchal prescription. This resistant sociality, a form of individualisation through creative association, could redefine gender relation within the domestic and public-political arena and make a desexualised and unthreatening space for political participation. It sanctioned non-familial and non-biological kinship and could enlarge the circle of empathy and affection beyond the family. For him, unless marriage was sacralised and desexualised, it could be an impediment to practising universal love (ahimsa). Gandhi's narrow view of kinship, centred on endogamous family-arranged marriage as the guardian of religion and social stability, thus lived alongside a free-wheeling enlargement of kinship through friendships enabled by his celibacy. His chosen lifestyle for non-biological families/households in his South African communes and Indian ashrams (residences for spiritual aspirants) suggests that marriage and family may have been personal obstacles. Sunil Khilnani notes that Gandhi was interested in abstinence in order to enjoy the pleasures of disinterested companionship and friendship, 'a bond devoid of instrumental aspects, purely voluntary, and between equals: compelled neither by legal contract nor instinctual passion' (2011, 66). Just as Gandhi's personal ascetism was self-devised and constituted from multiple sources, 
uncontrolled by gurus and institutions, this bond could be forged across differences of religion, caste, gender and nationality and transposed celibacy into secular forms of sociality.

\section{Towards a conclusion}

The difficulty of isolating religious from social individualisation, and extracting it from social, political and ideological constellations is evident. Here it is only possible to speak of individualisation as the singling out of a person within and against a determining context in a specific conjuncture.

The contradiction between prescription and practice as well as the mismatch of gender ideology and social experience in Besant and Gandhi are only partially explained by the gap between powerful, circulating colonial 'knowledges' and their fraught personal navigation of patriarchal marriage in Victorian England and India. In Besant, a quasi-socialist angst over hyper-individualisation, conservative identification with a supposedly cohesive and authoritative religious system as well as anxiety about democracy coagulate into the antimodern and create some temporal confusion. The antimodern invoked to resist the modern calls up a premodern, caste-bound Hindu womanhood perceived as coeval, still extant, as well as located in a past golden age in which the religious and secular were indivisible. An identitarian and pseudo-historical narrative of an anti-individualist ancient Hinduism gives authorial and textual authority to Besant as a self-nominated religious actor, serves to scaffold Theosophy's occult practices, and multiplies the sources of her individual social and political authority. Since an opposition between the modern and antimodern could hardly be stabilised in Britain, she tries to secure it in the seductive longevity, continuity and non-competitive matrices of Hindu womanhood and varna. Besant stood at an authorising intersection in which the (rebounding) legitimacy she gained from her double location performed a suppressive and conservative function vis a vis dissident and more radical currents in both Britain and India yet allowed her to escape the recommendations she made for Hindu women.

Gandhi excoriates a capitalist west and resists it in part through a quasiorientalist rendition of a textual and temporally distant 'east' of which womanhood and varna become the living remnants. The exaltation of womanhood and marriage participates in an indigenist and conservative anticolonialism. Situating a culturally differential model of Indian womanhood as the archetypal notyet-extinct premodern could overturn the stereotype of a libidinous orient or the pejorative sexualisation of indentured labour in South Africa and the Caribbean. But asserting its exemplary virtue as emblematic of a sacralised universe fell into 
another colonial and reformist stereotype that still coincided with conventional higher caste and new middle class patriarchal interests in India since it could be tied to the interrelated logics of seclusion, domestic labour and control of sexuality.

At one level, varna and ancient/contemporary Indian women become the deindividualised and embedded place-bearers against which Besant and Gandhi shaped their relatively unfettered and detraditionalised lives and religious practices. In other words, their individualisation is contrastive and thus the analogue of a modernity that could be secured only by immobilising its opposite: it is modern in structure and antimodern in content. Both tendencies self-consciously resist western individualism yet cement their individuality in part by imagining an ancient, altruistic, sacrificial and repressive social order which, along with some of the alternatives they proposed, was already entangled in transnational characterisations of the modern, premodern, antimodern and western individualism. Further, the softened borders between the premodern and antimodern put the combined weight of ancient prototypes and contemporary regimens on the shoulders of women and subordinate castes. In this early 20th century phase, Besant and Gandhi become singular individuals in their personal, religious, social and political practice through positing varna and womanhood as amorphous collectivities. This prescriptive and discursive deindividualisation is performative and could lead in several directions. It was either ignored, appropriated, contested, chastised, ridiculed or rejected by their contemporaries. Here too there was no direct path from ideology to social practice. Whereas the antimodern for Besant and Gandhi could be compensatory, legitimating and enabling, for Gandhi it is repeatedly diverted or disrupted by strong anticapitalist and radical currents or his own creative innovations. He alternates between affirming, destabilising, interrupting and reversing his antimodern positions, positions riddled with the volatile contradictions that he was to struggle with in later years.

\section{References}

Anderson, Nancy F. 1994. 'Bridging Cross-cultural Feminism: Annie Besant and Women's Rights in England and India, 1874-1933', Women's History Review 3.4. 563-80.

Beaumont, Matthew. 2010. 'Socialism and Occultism at the Fin de Siecle: Elective Affinities', Victorian Review 36.1. 217-32.

Besant, Annie. 1893. An Autobiography. London: Fisher Unwin.

Besant, Annie. 1900. 'Womanhood'. In The Queen's Daughters: An Anthology of Victorian Feminist Writings on India, 1857-1900, ed. Penelope Tuson, Ithaca: Ithaca Press.

Besant, Annie. 1901. Ancient Ideals in Modern Life; Four lectures delivered at the twenty-fifth anniversary meeting of the Theosophical Society, at Benares, December 1900. London and Benares: Theosophical Publishing Society. 
Besant, Annie. 1904. Hindu Ideals: For the Use of Hindu Students in the Schools of India.

Benares and London: Theosophical Publishing Society.

Besant, Annie. 1925. India. A Nation: a plea for Indian self-government. London: Jack.

Besant, Annie. 1942. Builder of New India. Adyar, Madras: The Theosophical Publishing House.

Besterman, Theodore. 1934. Mrs. Annie Besant: A Modern Prophet. London: Kegan Paul.

Blyth, Caroline. 2009. 'Unhappy Anniversary: Women, Marriage and Biblical Law in the Writings of Annie Besant'. In Strangely Familiar: Protofeminist Interpretations of Patriarchal Biblical Texts, eds. Nancy Calvert-Koyzis and Heather Weir, Atlanta: Society of Biblical Literature. 121-37.

Collier, Simon. 1990. 'Mercier's Enlightenment Utopia: progress and social ideals'. In The Enlightenment and its Shadows, eds. Peter Hulme and Ludmilla Jordanova, London: Routledge. 84-100.

Conrad, Sebastian. 2012. 'Enlightenment in Global History: A Historiographical Critique', American Historical Review 117.4. 999-1027.

Desai, Ashwin and Goolam Vahed. 2016. The South African Gandhi: Stretcher Bearer of Empire. Stanford: Stanford University Press.

Devji, Faisal. 2012. The Impossible Indian: Gandhi and the Temptation of Violence. Cambridge, Massachusetts: Harvard University Press.

Felski, Rita. 1995. The Gender of Modernity. Cambridge, Massachusetts: Harvard University Press.

Freeman, Michael. 1990. 'Human rights and the corruption of governments, 1789-1989'. In The Enlightenment and its Shadows, eds. Peter Hulme and Ludmilla Jordanova, London: Routledge. 163-83.

Fuchs, Martin. 2015. 'Processes of Religious Individualisation: Stocktaking and Issues for the Future', Religion 45.3. 330-43.

Gandhi, Leela. 2006. Affective Communities: Anticolonial Thought and the Politics of Friendship. Delhi: Permanent Black.

Gandhi, Leela. 2014. The Common Cause: Postcolonial Ethics and the Practice of Democracy, 1900-1955. Chicago: University of Chicago Press.

Gandhi, Mohandas K. 1943. To the Women. Ed. Anand Hingorani. Gandhi Series 2. Karachi: Hingorani.

Gandhi, Mohandas K. 1950. Hindu Dharma. Ahmedabad: Navjivan Publishing House.

Gandhi, Mohandas K. 1958-1982. Collected Works of Mahatma Gandhi. Delhi: Publications Division, Ministry of Information and Broadcasting, Government of India.

Gandhi, Mohandas K. 1988. Gandhi on Women. Ahmedabad: Navjivan Publishing House.

Gandhi, Mohandas K. 2010. Self-Restraint V. Self-Indulgence. Ahmedabad: Navjivan Publishing House.

Gandhi, Mohandas K. 2015. 'Hind Swaraj' and Other Writings. Ed. Anthony J. Parel. Cambridge: Cambridge University Press.

Habib, Irfan. 2011. The National Movement: Studies in Ideology and History. Delhi: Tulika Books.

Hardiman, David. 2013. Gandhi in His Time and Ours. Delhi: Permanent Black.

Hulme, Peter and Ludmilla Jordanova. 1990. 'Introduction'. In The Enlightenment and its Shadows, eds. idem and idem, London: Routledge. 1-15.

Hunt, James. 1993. Gandhi in London. New Delhi: Promilla.

Jacob, Margaret. 1981. The Radical Enlightenment: Pantheists, Freemasons and Republicans. London: Allen and Unwin. 
Jameson, Frederic. 2002. A Singular Modernity. London: Verso.

Jayawardena, Kumari. 1995. The White Woman's Other Burden: Western Women and South Asia during British Colonial Rule. London/New York: Routledge.

Kaiwar, Vasant. 2015. The Postcolonial Orient: The Politics of Difference and Project of Provincialising Europe. Chicago: Haymarket Books.

Khilnani, Sunil. 2011. 'Chemical Reactions in His Experiments with Truth', Outlook. 2 May 2011. 64-7.

Kumar, Aishwary. 2015. Radical Equality: Ambedkar, Gandhi, and the Risk of Democracy. Stanford: Stanford University Press.

Landes, Joan. 1988. Women and the Public Sphere in the Age of the French Revolution. Ithaca: Cornell University Press.

Lelyveld, Joseph. 2012. Great Soul: Mahatma Gandhi and His Struggles with India. New York: Vintage Press.

Malinar, Angelika. 2018. "Karmic histories and the "synthesis" of "East and West". Annie Besant on Hinduism', in: Asia and Europe - Interconnected: Agents, Concepts, and Things, ed. Angelika Malinar and Simone Müller. Wiesbaden: Harrassowitz.

Marx, Karl and Friedrich Engels. 1978. 'Manifesto of the Communist Party'. In The Marx-Engels Reader, ed. and trans. Robert C. Tucker, New York: Norton. 469-500.

Miller, Elizabeth C. 2009. 'Body, Spirit, Print: The Radical Autobiographies of Annie Besant and Helen and Olivia Rossetti’, Feminist Studies 35.2. 243-73.

Miller, Elizabeth C. 2013. Slow Print: Literary Radicalism and Late Victorian Print Culture. Stanford: Stanford University Press.

Müller, Max. 1882. India: What Can It Teach Us. Delhi: Munshiram Manoharlal.

Natarajan, Nalini. 2013. Atlantic Gandhi: The Mahatma Overseas. Delhi: Sage.

Owen, Alex. 2004. The Place of Enchantment. Chicago: University of Chicago Press.

Parel, Anthony. 2015. 'Introduction'. In Hind Swaraj and Other Writings, Mohandas K. Gandhi, ed. idem, Cambridge: Cambridge University Press. xii-xc.

Pateman, Carole. 1988. 'The Fraternal Social Contract'. In Civil Society and the State: New European Perspectives, ed. John Keane, London: Verso. 101-14.

Samarendra, Padmanabh. 2010. 'Between Number and Knowledge: Career of Caste in Colonial Census'. In Caste in History, ed. Ishita Banerjee Dube, Delhi: Oxford University Press. 46-66.

Sangari, Kumkum. 2004. 'The Indigenist to the Anti-modern: Annie Besant's Hindu Ideals', Contemporary India 3.1.1-22.

Sangari, Kumkum. 1999. Politics of the Possible: Essays on Gender, History, Narratives, Colonial English. Delhi: Tulika Books.

Schneer, Jonathan. 2001. London 1900: The Imperial Metropolis. New Haven/London: Yale University Press.

Skaria, Ajay. 2016. Unconditional Equality: Gandhi's Religion of Resistance. Minneapolis: University of Minnesota Press.

Stoler, Ann L. 2016. Duress: Imperial Durabilities in Our Times. Durham/London: Duke University Press.

Veer, Peter van der. 2001. Imperial Encounters: Religion and Modernity in India and Britain. Princeton: Princeton University Press.

Viswanathan, Gauri. 1998. Outside the Fold: Conversion, Modernity, and Belief. Princeton: Princeton University Press. 